This item was submitted to Loughborough's Research Repository by the author.

Items in Figshare are protected by copyright, with all rights reserved, unless otherwise indicated.

\title{
New build: materials, techniques, skills and innovation
}

PLEASE CITE THE PUBLISHED VERSION

http://www.sciencedirect.com/science/article/pii/S0301421508004771

PUBLISHER

(c) Elsevier

VERSION

AM (Accepted Manuscript)

LICENCE

CC BY-NC-ND 4.0

REPOSITORY RECORD

Glass, Jacqueline, Andrew R.J. Dainty, and Alistair G.F. Gibb. 2019. "New Build: Materials, Techniques, Skills and Innovation". figshare. https://hdl.handle.net/2134/9037. 
This item was submitted to Loughborough's Institutional Repository (https://dspace.lboro.ac.uk/) by the author and is made available under the following Creative Commons Licence conditions.

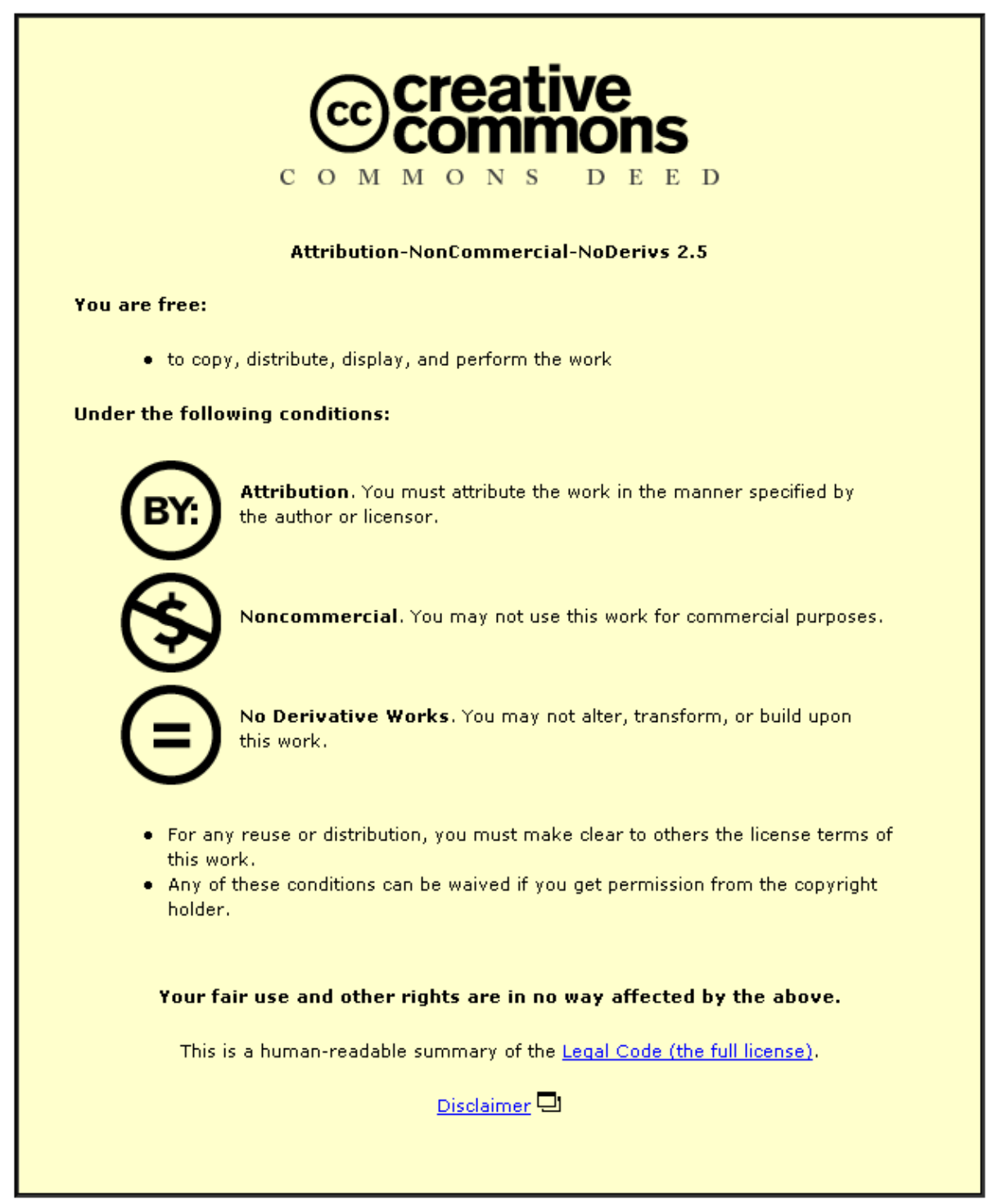

For the full text of this licence, please go to: http://creativecommons.org/licenses/by-nc-nd/2.5/ 


\section{New Build: materials, techniques, skills and innovation}

State-of-Science Review: Sustainable Energy Management and the Built Environment (SEMBE)

Dr Jacqueline Glass

Department of Civil and Building Engineering, Loughborough University

Professor Andrew R.J. Dainty

Department of Civil and Building Engineering, Loughborough University

Professor Alistair G.F. Gibb

Department of Civil and Building Engineering, Loughborough University

For Foresight Report 2008

FORESI GHT PROJ ECT ON SUSTAINABLE ENERGY MANAGEMENT AND THE BUILT ENVIRONMENT

Version date: 14 February 2008

FINAL VERSION, FOLLOWING PEER REVIEW

Glass, J., Dainty, A.R.J., \& Gibb, A.G.F. 2008, New build - materials, techniques, skills and innovation, Energy Policy, Elsevier, Nov 2008, vol 36, pp. 4534-4538, ISSN 03014215, www.sciencedirect.com/science/journal/03014215 


\begin{abstract}
The transition to secure, sustainable low energy systems will have a significant effect on the way in which we design and construct new buildings. In turn, the new buildings that are constructed will play a critical role in actually delivering the better performance that would be expected from such a transition. With UK buildings accounting for about half of all $\mathrm{CO}_{2 \mathrm{e}}$ consumed, there is clearly great urgency in ensuring that energy is used efficiently in buildings but also that new building stock is better able to cope with whatever the future holds. Most energy used in buildings goes towards heating, lighting and cooling, but with a growing percentage being consumed by domestic appliances, computers and electrical equipment. Actual energy consumption is clearly a product of a number of factors, including individual behaviours and expectations, the energy efficiency of appliances and the building envelope. This review focuses on the latter component - that of the building itself, its design and construction. It discusses the issues faced by the construction industry today, suggesting that major changes are needed relating to materials, techniques, skills and innovation. The review moves on to consider future advances to 2050 and beyond, including developments in ICT, novel materials, skills and automation, servitization, performance measurement and reporting, and resilience. A vision of the new build construction industry in 2050 is presented, followed by recommendations that are particularly relevant to policy makers, pan-industry organisations and construction companies.
\end{abstract}




\section{STATE OF CURRENT SCIENCE - PRESSURES ON BUILDINGS TODAY}

For the UK's building stock to deliver better performance, a range of important problems must be addressed. Some have plagued construction for many years and some are unlikely to change for many more.

The first problem is that the rate of replacement of buildings in the UK, particularly in housing, is low. About two-thirds of the buildings that will exist in 2050 are already built and being used today. Only about a third of building stock will be new and will have been built in response to issues such as climate change. The crux is what any new stock could and should be expected to contribute. One could argue that all new buildings should be super-efficient or carbon-negative, and should be designed and constructed in such a way that they effectively 'make up for' all the energy-laggard stock that will still be in use in 50 years. But this alone will not offer a panacea. There will also need to be major changes to existing buildings through refurbishment, envelope improvement and equipment replacement.

Secondly, within the domestic sector at least, significant changes to address sustainability are afoot. Building Regulations have changed to respond to European legislation on energy efficiency, and the Code for Sustainable Homes sets new standards up to 'carbon neutral' (DCLG, 2006). There are calls for such schemes to be extended to non-domestic properties to widen the benefits and spread environmental accounting. Sustainability assessment tools such as BREEAM, the Building Research Establishment Environmental Assessment Method, are growing in popularity. In some cases it is mandatory to attain certain levels of achievement to satisfy new procurement requirements, particularly for public sector projects. Clearly this challenges designers, materials providers and constructors. Specifiers are becoming more interrogative in their decision making as a result.

Thirdly, the construction industry as a whole has been subjected to decades of criticism for its lack of innovation, poor safety record, inconsiderate operational environment and general under-performance (e.g. Egan, 1998; 
Fairclough, 2002). Recent initiatives call for significant culture change in the industry, such as better team working, procurement practices and sustainability (Egan, 2002). Unfortunately, a substantial, unsophisticated section of the industry barely meets existing requirements. It creates environmental problems, kills people on unsafe sites and does little more than provide the physical actuality of the building itself. This under-performing legacy cannot continue. To their credit, many companies can no longer be described in such terms, but achieving new targets on safety (Defra/DTI/DCLG, 2007) may still be difficult.

Fourthly, there are still inadequate skills, and too few skilled operatives and professional staff to serve the industry's needs. The skills shortage in the UK has been mitigated to some extent by migrant labour. But there are specific skills gaps, for instance in developing sustainable communities (Egan, 2004; Pearce, 2003). This creates vulnerability and it is understandable that government and industry are again examining the viability of off-site construction and prefabrication, and on-site advances such as mobile communications and robotics, as means of reducing the reliance on site labour (e.g. ECTP, 2005). But even these proposals do not address professional skills shortages.

Finally, there are external factors such as oil depletion, water supply problems, globalisation (Harty et al., 2007) and the broad 'resilience' agenda, which includes natural and man-made hazards such as climate change, terror threats, wind-storms and flooding (Arup, 2006; Bosher et al., 2007). Any or all of these has the potential to very significantly affect the way we build, but at the moment there is only localised and sporadic change, for example, in response to specific incidents such as tidal and river flooding, or blast protection to critical infrastructure.

Replacement rates, sustainability, a lack of innovation, skills needs and external factors are five major pressures which demonstrate that to create more sustainable, energy-efficient and resilient buildings is a transition that requires wholesale change, both top-down and bottom-up. This suggests that a systems approach would be appropriate to address such a combination of 
supply and demand pressures. Indeed, Gann (2000, p. 195) reminds us of the danger of 'overemphasising the physical characteristics of construction'; considering the building in a detached way, separate from its environment and its social setting. In the same vein, Elzen et al. (2004) and others emphasise the importance of including an analysis of the socio-technical systems that surround new buildings when thinking about their future use. With this notion in mind, Table 1 presents a PEST analysis of relevant enablers and barriers faced by the industry in developing better new build. It indicates that there are key challenges ahead, some of which echo the ongoing concerns about the industry's performance cited above.

Table 1: PEST analysis of enablers and barriers in new build construction

\begin{tabular}{|c|c|c|c|}
\hline POLITICAL & & SOCIAL & \\
\hline Enablers & Barriers & Enablers & Barriers \\
\hline $\begin{array}{l}\text { - } \text { Building } \\
\text { Regulations } \\
\text { - Energy policy } \\
\text { - Sustainable } \\
\text { Construction } \\
\text { strategy } \\
\text { - Planning policy } \\
\text { - Waste reduction } \\
\text { agenda } \\
\text { - Climate change } \\
\text { agenda } \\
\text { - Security and } \\
\text { resilience agenda }\end{array}$ & $\begin{array}{l}\text { - 'Stick'-based } \\
\text { legislation } \\
\text { - Lack of teeth in } \\
\text { legislation } \\
\text { - UK seen as } \\
\text { unnecessarily } \\
\text { restrictive } \\
\text { legislative } \\
\text { environment for } \\
\text { manufacture }\end{array}$ & $\begin{array}{l}\text { - Rising consumer } \\
\text { engagement } \\
\text { - Interest in resilience } \\
\text { to climate and man- } \\
\text { made hazards } \\
\text { - Inclusion in } \\
\text { professional curricula } \\
\text { - New taught courses } \\
\text { on sustainability } \\
\text { issues }\end{array}$ & $\begin{array}{l}\text { - Regionality: diverse } \\
\text { contexts } \\
\text { - Skills shortage } \\
\text { - Migrant labour } \\
\text { - Need for CPD/skills } \\
\text { development } \\
\text { - Construction's } \\
\text { reputation - dust } \\
\text { and noise } \\
\text { - Lack of capacity and } \\
\text { know-how } \\
\text { - Too much green } \\
\text { 'spin' and marketing }\end{array}$ \\
\hline ECONOMIC & & TECHNOLOGICAL & \\
\hline Enablers & Barriers & Enablers & Barriers \\
\hline $\begin{array}{l}\text { - Fiscal-based } \\
\text { legislation (Landfill } \\
\text { Tax etc.) } \\
\text { - Cost of moving } \\
\text { goods by road } \\
\text { - VAT } \\
\text { - Carbon accounting } \\
\text { methods } \\
\text { - Sustainable } \\
\text { procurement } \\
\text { action plan }\end{array}$ & $\begin{array}{l}\text { - Negative investor } \\
\text { views of industry } \\
\text { - Threat from } \\
\text { imports, balance } \\
\text { of trade } \\
\text { - Cost of UK } \\
\text { production } \\
\text { - Land/house } \\
\text { prices } \\
\text { - Energy costs }\end{array}$ & $\begin{array}{l}\text { - Drive for low carbon } \\
\text { buildings } \\
\text { - Carbon footprinting } \\
\text { - Demand for ISO and } \\
\text { EMAS } \\
\text { - Mobile computing } \\
\text { and ICT } \\
\text { - Logistics solutions, } \\
\text { materials } \\
\text { consolidation centres } \\
\text { - Change driven by } \\
\text { health and safety }\end{array}$ & $\begin{array}{l}\text { - Lack of R\&D } \\
\text { - Slow rate of change } \\
\text { of building stock } \\
\text { - Poor client } \\
\text { knowledge base } \\
\text { - Poor specification } \\
\text { writing and } \\
\text { estimating } \\
\text { - Materials cost and } \\
\text { availability } \\
\text { - Lack of data and } \\
\text { evidence }\end{array}$ \\
\hline
\end{tabular}


Today's pressures and these enablers and barriers suggest a clear need for change. Ultimately, it is the construction industry that must deliver the building blocks of a secure, sustainable, low-carbon society. However, in construction the normative position is overwhelmingly one of begrudging response. It is very rarely proactive. In the short term at least, change needs to be imposed top-down, and supported bottom-up with encouragement and reward. The transition that is needed is so large that visible change will almost certainly be needed in the new build sector.

Harty et al.'s (2007) review of construction futures literature offers useful insights in this regard. It confirms that we should expect imminent changes in:

- what we require materials to do (e.g. be low carbon, be resilient, or be adaptive to temperature change)

- what we expect of building techniques, production methods and construction sites (e.g. be more considerate, attract regional staff, or use more robotics)

- what we require people to know (e.g. be more informed on specification and design, or more IT-literate)

- what we will expect of innovation, $R \& D$ and management (e.g. be much more revolutionary, rather than incremental, and reward change leaders).

One of the reports analysed by Harty et al. (2007) was the Australian Construction 2020 (Hampson and Brandon, 2004). It offers some useful insights and nine specific visions covering sustainability, client needs, welfare, ICT and processes in construction and product manufacture. Many of these are common to the majority of recommendations in other key texts on construction innovation. We can conclude that there are some collectively held concerns about the industry and a number of pressures being brought to bear, and that a systems approach could shed new light on the problem. 


\section{FUTURE ADVANCES TO 2050 AND BEYOND}

Changes on the scale proposed by Harty et al. (2007) would have considerable impact on today's construction industry, particularly if they all happened at the same time. But past innovation and change in new build has tended to be incremental. This means that the most significant challenge would be to overcome the industry's inertia and propel it forward. The sector is viewed by investors as a poor prospect and is described as backward looking, too conservative, and with low profit margins. These characteristics make radical change in the new build arena an unlikely prospect, but gradual change a real possibility. This means that the industry could lag behind and not be in a position to deliver the new buildings that government and society require, delaying improvements in the performance of buildings.

Taking this context into account, Table 2 outlines a number of key advances that could occur in the future, together with their potential benefits and characteristics. These are a few of the plausible, appropriate and reasonably likely changes, and are categorised under four broad headings.

Any of these advances could occur at any time in the next fifty years and it is also highly unlikely that none will. It is not the purpose of this review to speculate wildly. A balance is needed between over-simplifying and overcomplicating the debate. This review stops short of trying to present highly intricate representations of the new build question. That said, the following discussion section does propose a number of key interactions and relationships between the eight key advances described in Table 2. 
Table 2: Key advances in new build

\begin{tabular}{|c|c|c|c|c|c|c|}
\hline & $\begin{array}{l}\text { Environmental } \\
\text { benefits }\end{array}$ & $\begin{array}{l}\text { Economic } \\
\text { benefits }\end{array}$ & Social benefits & Applications & $\begin{array}{l}\text { Likelihood of } \\
\text { success }\end{array}$ & $\begin{array}{l}\text { Ramifications for } \\
\text { capabilities }\end{array}$ \\
\hline \multicolumn{7}{|l|}{ ADVANCES IN MATERIALS } \\
\hline $\begin{array}{l}\text { Docile and aggressive materials: new } \\
\text { products with markedly better energy } \\
\text { performance, resilience or robustness to } \\
\text { natural and man-made hazards etc. (e.g. } \\
\text { smart, nanotechnologically modified, ICT- } \\
\text { driven, phase change materials). } \\
\text { Combinations of these aggressive (quick, } \\
\text { responsive, more expensive) and docile } \\
\text { (ambivalent, slower to respond, cheaper) } \\
\text { most likely in practice. }\end{array}$ & $\begin{array}{l}\text { - Reduced energy } \\
\text { consumption. } \\
\text { - Reduced carbon } \\
\text { emissions in use. } \\
\text { - Reduced } \\
\text { embodied } \\
\text { energy. } \\
\text { - Better product } \\
\text { environmental } \\
\text { profiles. }\end{array}$ & $\begin{array}{l}\text { - Lower utilities } \\
\text { bills. } \\
\text { - Lower } \\
\text { maintenance } \\
\text { costs. } \\
\text { - Higher value } \\
\text { products. }\end{array}$ & $\begin{array}{l}\text { - Safer, more } \\
\text { comfortable } \\
\text { buildings. } \\
\text { - Future-proof } \\
\text { against climate } \\
\text { change. } \\
\text { - Need to 'tune' a } \\
\text { building creates } \\
\text { a new } \\
\text { profession. }\end{array}$ & $\begin{array}{l}\text { - Insulation, wall } \\
\text { and roof } \\
\text { coverings, } \\
\text { fittings, windows. } \\
\text { Many docile } \\
\text { materials already in } \\
\text { existence (e.g. } \\
\text { masonry, stone, } \\
\text { concrete). }\end{array}$ & $\begin{array}{l}\text { - Cost is a key } \\
\text { constraint. } \\
\text { - Aggressive } \\
\text { materials } \\
\text { limited to few, } \\
\text { high value } \\
\text { applications. }\end{array}$ & $\begin{array}{l}\text { - Major investment for } \\
\text { manufacturers. } \\
\text { - Implications for } \\
\text { standards, testing } \\
\text { and specification } \\
\text { writing. } \\
\text { - Interaction } \\
\text { mechanisms and } \\
\text { communication } \\
\text { between docile and } \\
\text { aggressive materials } \\
\text { needs research. }\end{array}$ \\
\hline $\begin{array}{l}\text { Low waste to no waste: materials and } \\
\text { products with significant waste/recycled } \\
\text { content; closed loop production and } \\
\text { operation cycles to eliminate landfill and } \\
\text { hazardous waste. Commonly available } \\
\text { waste streams give way to advanced } \\
\text { wastes, such as consumer waste, high-tech } \\
\text { production streams (such as vehicles, IT } \\
\text { equipment). New and unconventional } \\
\text { companies form out of innovative waste } \\
\text { stream agreements. }\end{array}$ & $\begin{array}{l}\text { - } \text { Reduced } \\
\text { embodied } \\
\text { energy. } \\
\text { - Less construction } \\
\text { and demolition } \\
\text { C\&D waste. } \\
\text { - Less pressure on } \\
\text { landfill. } \\
\text { - Less pollution. } \\
\text { - Better product } \\
\text { environmental } \\
\text { profiles. }\end{array}$ & $\begin{array}{l}\text { - Reduced } \\
\text { materials } \\
\text { costs. } \\
\text { - Higher value } \\
\text { products. } \\
\text { - New } \\
\text { companies } \\
\text { form. }\end{array}$ & $\begin{array}{l}\text { - Fewer landfill } \\
\text { sites. } \\
\text { - Uses domestic } \\
\text { waste materials. } \\
\text { - New job roles } \\
\text { emerge. }\end{array}$ & $\begin{array}{l}\text { Wall, floor, roof, } \\
\text { insulation, fill } \\
\text { materials, fittings } \\
\text { and finishes. }\end{array}$ & $\begin{array}{l}\text { - Very likely in } \\
\text { cases where } \\
\text { continual } \\
\text { waste streams } \\
\text { exist. } \\
\text { - Limited if there } \\
\text { is no waste to } \\
\text { include. }\end{array}$ & $\begin{array}{l}\text { - Changes to } \\
\text { manufacturing } \\
\text { process. } \\
\text { - Implications for } \\
\text { standards, testing } \\
\text { and specification } \\
\text { writing. } \\
\text { - Supply and demand } \\
\text { mechanism critical } \\
\text { to success. } \\
\text { - Availability, regional } \\
\text { supply chains are } \\
\text { also important. }\end{array}$ \\
\hline
\end{tabular}




\begin{tabular}{|c|c|c|c|c|c|c|}
\hline & $\begin{array}{l}\text { Environmental } \\
\text { benefits }\end{array}$ & $\begin{array}{l}\text { Economic } \\
\text { benefits }\end{array}$ & Social benefits & Applications & $\begin{array}{l}\text { Likelihood of } \\
\text { success }\end{array}$ & $\begin{array}{l}\text { Ramifications for } \\
\text { capabilities }\end{array}$ \\
\hline \multicolumn{7}{|c|}{ ADVANCES IN TECHNIQUES AND PRODUCTION } \\
\hline $\begin{array}{l}\text { Super-automatic construction: on- and off- } \\
\text { site production methods use more ICT, lower } \\
\text { energy vehicles and robotics; mechanical } \\
\text { means and tower cranes are deemed unfit } \\
\text { for human use and there is a much greater } \\
\text { level of automation and remote control of } \\
\text { machinery; larger machines incorporate PV } \\
\text { cells and energy saving devices. }\end{array}$ & $\begin{array}{l}\text { - Lower energy } \\
\text { use. Smaller } \\
\text { footprint } \\
\text { construction } \\
\text { sites. } \\
\text { - Lower } \\
\text { environmental } \\
\text { impact ratings for } \\
\text { plant. } \\
\end{array}$ & $\begin{array}{l}\text { - Plant } \\
\text { manufacture } \\
\text { becomes } \\
\text { high-tech } \\
\text { industry. } \\
\text { - Faster } \\
\text { construction. } \\
\text { - Lower energy } \\
\text { bills. } \\
\end{array}$ & $\begin{array}{l}\text { - Safer } \\
\text { construction } \\
\text { sites. } \\
\text { - Fewer } \\
\text { accidents. } \\
\text { - Zero deaths. } \\
\text { - New careers } \\
\text { emerge. }\end{array}$ & $\begin{array}{l}\text { - Potentially } \\
\text { extensive, but } \\
\text { construction has } \\
\text { traditionally been } \\
\text { reluctant to } \\
\text { embrace ICT and } \\
\text { robotics. }\end{array}$ & $\begin{array}{l}\text { - High capital } \\
\text { costs of } \\
\text { equipment } \\
\text { could limit. } \\
\text { - Hire } \\
\text { companies } \\
\text { most likely to } \\
\text { invest. }\end{array}$ & $\begin{array}{l}\text { - Relies on different } \\
\text { labour force, more } \\
\text { skilled operatives. } \\
\text { - Dependent on } \\
\text { contractors changing } \\
\text { their operations to } \\
\text { suit. }\end{array}$ \\
\hline $\begin{array}{l}\text { Super-resilient buildings: construction } \\
\text { methods reflect the need to build for a very } \\
\text { adaptive society; 'anything could happen } \\
\text { anytime' attitude means buildings have to } \\
\text { accommodate changes in work patterns, } \\
\text { family patterns, climate change, energy } \\
\text { supply change; insurers, pension funds, } \\
\text { developers and serviced office providers } \\
\text { merge to form 'city block' gurus. }\end{array}$ & $\begin{array}{l}\text { - Less distance } \\
\text { commuted per } \\
\text { person per } \\
\text { annum. } \\
\text { - Lower carbon } \\
\text { and energy } \\
\text { consumption. } \\
\text { - Compact } \\
\text { dwelling patterns } \\
\text { save fuel. }\end{array}$ & $\begin{array}{l}\text { - New types of } \\
\text { mortgages/ } \\
\text { investments in } \\
\text { city blocks, } \\
\text { not houses. } \\
\text { - Less upheaval } \\
\text { after } \\
\text { disasters. } \\
\text { - Lower } \\
\text { insurance } \\
\text { fees. } \\
\text { - New local } \\
\text { companies } \\
\text { and alliances } \\
\text { form. } \\
\end{array}$ & $\begin{array}{l}\text { - Consumers are } \\
\text { more confident } \\
\text { about buying } \\
\text { shared } \\
\text { properties. } \\
\text { - People live and } \\
\text { work locally. } \\
\text { - Communities } \\
\text { thrive and are } \\
\text { sustainable. }\end{array}$ & $\begin{array}{l}\text { - High value land } \\
\text { and sites will be } \\
\text { first target. } \\
\text { - Might also work } \\
\text { as new towns or } \\
\text { peri-urban } \\
\text { villages. }\end{array}$ & $\begin{array}{l}\text { - Dependent on } \\
\text { major changes } \\
\text { in society. } \\
\text { - Unlikely to be } \\
\text { widespread } \\
\text { outside of city } \\
\text { areas. }\end{array}$ & $\begin{array}{l}\text { - Major changes } \\
\text { needed to property } \\
\text { market structure. } \\
\text { - New house designs } \\
\text { and materials } \\
\text { needed. }\end{array}$ \\
\hline \multicolumn{7}{|l|}{ ADVANCES IN SKILLS (THE PEOPLE AGENDA) } \\
\hline $\begin{array}{l}\text { IT-literate artisans: those tradespeople who } \\
\text { remain are highly specialist and sought after; } \\
\text { a new breed of IT-literate and deft site } \\
\text { workers emerge to control new machines; } \\
\text { skilled posts are better paid, so people settle } \\
\text { and the number of itinerant subbies is near } \\
\text { to zero. }\end{array}$ & $\begin{array}{l}\text { - Less distance } \\
\text { commuted per } \\
\text { worker per } \\
\text { annum. } \\
\text { - Lower fuel } \\
\text { emissions. }\end{array}$ & $\begin{array}{l}\text { - More stable } \\
\text { communities. } \\
\text { - Higher } \\
\text { productivity } \\
\text { sites. } \\
\text { - Better-paid } \\
\text { workers. } \\
\text { - Stable } \\
\text { workforces. } \\
\text { - Less 'cash-in- } \\
\text { hand' work. }\end{array}$ & $\begin{array}{l}\text { - People work } \\
\text { fewer hours, but } \\
\text { for more pay. } \\
\text { - More time with } \\
\text { families. }\end{array}$ & $\begin{array}{l}\text { - Fewer overall } \\
\text { tradespeople still } \\
\text { likely. } \\
\text { - Skilled operators } \\
\text { will emerge if the } \\
\text { machines do. }\end{array}$ & $\begin{array}{l}\text { - Good provided } \\
\text { people } \\
\text { actually want } \\
\text { to join the } \\
\text { industry. } \\
\text { - Otherwise } \\
\text { itinerant and } \\
\text { migrant labour } \\
\text { remain. }\end{array}$ & $\begin{array}{l}\text { - Will need new NVQs } \\
\text { for skilled operators. } \\
\text { - Must sustain a body } \\
\text { of traditional } \\
\text { craftspeople too. }\end{array}$ \\
\hline
\end{tabular}




\begin{tabular}{|c|c|c|c|c|c|c|}
\hline & $\begin{array}{l}\text { Environmental } \\
\text { benefits }\end{array}$ & $\begin{array}{l}\text { Economic } \\
\text { benefits }\end{array}$ & Social benefits & Applications & $\begin{array}{l}\text { Likelihood of } \\
\text { success }\end{array}$ & $\begin{array}{l}\text { Ramifications for } \\
\text { capabilities }\end{array}$ \\
\hline $\begin{array}{l}\text { Single integrated professional body: the } \\
\text { changes in building design and technology } \\
\text { are reflected by a shift in professional } \\
\text { education and governance; new career } \\
\text { paths emerge and are much more attractive } \\
\text { to young people, who are IT-literate and } \\
\text { committed to energy and environmental } \\
\text { protection; people outside traditional roles } \\
\text { can join the industry more easily. }\end{array}$ & $\begin{array}{l}\text { - Issues more } \\
\text { likely to be } \\
\text { embedded in } \\
\text { projects from day } \\
\text { one. } \\
\text { - More people } \\
\text { available to } \\
\text { assess } \\
\text { performance too. }\end{array}$ & $\begin{array}{l}\text { - } \text { More } \\
\text { profitable } \\
\text { projects. } \\
\text { - Better } \\
\text { expertise } \\
\text { available. }\end{array}$ & $\begin{array}{l}\text { - More career } \\
\text { paths available. } \\
\text { - Access for more } \\
\text { people to } \\
\text { industry. }\end{array}$ & $\begin{array}{l}\text { - Would apply to } \\
\text { all built } \\
\text { environment } \\
\text { professions. }\end{array}$ & $\begin{array}{l}\text { - Limited in the } \\
\text { short term } \\
\text { owing to } \\
\text { dominance of } \\
\text { professional } \\
\text { bodies. }\end{array}$ & $\begin{array}{l}\text { - Possibility for new } \\
\text { career paths. } \\
\text { - Possibility that those } \\
\text { in energy and } \\
\text { security fields could } \\
\text { do conversion } \\
\text { courses. }\end{array}$ \\
\hline \multicolumn{7}{|c|}{ ADVANCES IN INNOVATION, R\&D AND MANAGEMENT } \\
\hline $\begin{array}{l}\text { Measure or perish: everything is measured } \\
\text { and profiled; live display boards on buildings } \\
\text { and sites show energy and resource use; } \\
\text { nothing moves without being measured; } \\
\text { resource accountants are the new quantity } \\
\text { surveyors QSs; people's CVs include a } \\
\text { record of their personal and career carbon } \\
\text { footprints. }\end{array}$ & $\begin{array}{l}\text { - Waste is } \\
\text { eliminated. } \\
\text { - Reduced energy } \\
\text { consumption. } \\
\text { - Continual } \\
\text { reinforcement of } \\
\text { importance of } \\
\text { these issues, } \\
\text { even at street } \\
\text { level. }\end{array}$ & $\begin{array}{l}\text { - Profitability } \\
\text { increases } \\
\text { because of } \\
\text { less waste. }\end{array}$ & $\begin{array}{l}\text { - Society can } \\
\text { 'see' what is } \\
\text { going on. } \\
\text { - Government } \\
\text { has more } \\
\text { accurate data. } \\
\text { - New career } \\
\text { paths emerge. }\end{array}$ & $\begin{array}{l}\text { Particularly } \\
\text { useful for energy } \\
\text { and resource } \\
\text { use. }\end{array}$ & $\begin{array}{l}\text { - Good. Likely } \\
\text { to fit in with } \\
\text { legislative } \\
\text { framework. } \\
\text { - Standards and } \\
\text { components } \\
\text { already in } \\
\text { place. } \\
\text { - Popular issue. }\end{array}$ & $\begin{array}{l}\text { - Existing QS courses } \\
\text { will need to change. } \\
\text { - HR record staff } \\
\text { carbon footprints } \\
\text { annually. } \\
\text { - Employers rate CVs } \\
\text { accordingly. }\end{array}$ \\
\hline $\begin{array}{l}\text { Licence to operate: contractors cannot } \\
\text { build without Corporate Social Responsibility } \\
\text { CSR and environmental management } \\
\text { certification; a few major companies survive } \\
\text { after legislation and consumer pressure } \\
\text { means projects are only commissioned from } \\
\text { 'change leaders' and there are higher } \\
\text { barriers to entry (including automation). }\end{array}$ & $\begin{array}{l}\text { - Zero } \\
\text { environmental } \\
\text { incidents. } \\
\text { - Better protection } \\
\text { for environment } \\
\text { and species. }\end{array}$ & $\begin{array}{l}\text { - Consumer } \\
\text { and investor } \\
\text { confidence in } \\
\text { the industry } \\
\text { increases. } \\
\text { - Stocks rise in } \\
\text { value, so do } \\
\text { profits and } \\
\text { salaries. }\end{array}$ & $\begin{array}{l}\text { - More } \\
\text { considerate } \\
\text { sites. } \\
\text { - Public has more } \\
\text { confidence in } \\
\text { industry. }\end{array}$ & $\begin{array}{l}\text { - ISO14001, } \\
\text { Considerate } \\
\text { Constructors } \\
\text { Scheme, } \\
\text { BS8900 and/or } \\
\text { NHBC could be } \\
\text { all part of the } \\
\text { scheme. }\end{array}$ & $\begin{array}{l}\text { - Good. Likely } \\
\text { to fit in with } \\
\text { legislative } \\
\text { framework. } \\
\text { - Standards and } \\
\text { components } \\
\text { already in } \\
\text { place. }\end{array}$ & $\begin{array}{l}\text { - Industry will need } \\
\text { more environmental } \\
\text { experts (CEnv). } \\
\text { - More training } \\
\text { courses needed. }\end{array}$ \\
\hline
\end{tabular}


This review has outlined eight key advances that could be expected in the new build sector. It has identified advances on both the supply and demand sides as indicated in Table 3, which also outlines some of the key drivers that will influence the progress of these advances.

Table 3: A simple, systems view of the key advances

\begin{tabular}{|c|c|c|}
\hline $\begin{array}{l}\text { Supply side: industry, } \\
\text { technologies and skills } \\
\text { (driven by innovation and } \\
\text { R\&D) }\end{array}$ & $\begin{array}{l}\text { Key drivers in surrounding } \\
\text { socio-technical and economic } \\
\text { systems. }\end{array}$ & $\begin{array}{l}\text { Demand side: users, customers } \\
\text { and clients (driven by new and } \\
\text { changing expectations). }\end{array}$ \\
\hline $\begin{array}{l}\text { - Docile and aggressive } \\
\text { materials } \\
\text { - Low waste to no waste } \\
\text { - Super-automatic } \\
\text { construction } \\
\text { - IT-literate artisans }\end{array}$ & $\begin{array}{l}\text { - Planning policy } \\
\text { - Energy legislation } \\
\text { - Building regulations } \\
\text { - Customer choice } \\
\text { - Property values } \\
\text { - Energy costs } \\
\text { - Insurance prices } \\
\text { - Efficiency } \\
\text { - Quality assurance } \\
\text { - Servitisation }\end{array}$ & $\begin{array}{l}\text { - Super-resilient buildings } \\
\text { - Single, integrated professional } \\
\text { body } \\
\text { - Measure or perish } \\
\text { - Licence to operate }\end{array}$ \\
\hline
\end{tabular}

These drivers will interconnect the advances in practical terms. For example, servitisation, bundling customer-focused goods and services to add value (Vandemerwe and Rada, 1988), will cause construction firms to reinvent themselves as through-life service providers or facilities managers. Private Finance Initiative (PFI) contractors will join forces with energy managers to enhance their product sensitivity, and will become capable of installing highly valuable energy saving and generating devices as a matter of course. This will make measurement and compliance in an increasingly demanding regulatory environment much easier. Increased energy legislation and building regulation at a national and international level will mean that the building industry will be much more closely regulated. Processes will be managed to avoid the exorbitant fines that will be levied for energy and environment violations. This shift will be supported by the emergence of multidisciplinary practitioners who belong to a single, integrated professional body. 
These high-calibre professionals will occupy well-paid positions with roles that extend from building design to the provision of through-life services.

The pressures for process efficiency, zero accidents on sites, cleanliness and energy efficiency will combine to further increase the use of off-site construction. Sites will be automation-enabled, with only robots allowed to work in hazardous areas. The major construction products manufacturers will have formed a strategic alliance with nanotech companies to develop economical self-cleaning and selfreporting materials, products and building systems. The need for these new products and manufacturing methods also stems from the increasing demand for buildings that are robust, resilient and resistant to extreme weather.

\section{Recommendations}

The scope of the advances described here is extensive, and some or all of them could happen at any time in the near future. Most would be dependent on changes in policy, institutional frameworks or individuals' choices and behaviour, as shown in Table 3. We cannot tell how likely such change in the construction industry is to occur. It is more likely that changes will emerge because of actions by government, clients, local authorities or perhaps professional groups than via unprompted action by the construction industry. To help implement these advances in the long term, a number of strategic recommendations for further R\&D can be made:

- A central body or government agency should be commissioned to regulate, standardise and monitor all sustainability assessments and energy measurement methodologies.

- Regional development agencies should be asked to set aside demonstration city blocks for new resilient homes and businesses.

- Standard-setting bodies should be tasked with developing a tough build quality and energy compliance regime for construction.

- A pan-institutional think tank should be established to generate new routes through education and career paths into practice.

- High-level sector organisations should be asked to devise ways of developing change leadership. 
- Major contractors should be invited to respond regarding subcontractor commuting, which is the cause of much fossil fuel use, automation on site, and new professional paths.

- Research should be commissioned to investigate the performance of combinations of docile and aggressive materials.

- A testing programme of high-tech construction equipment should be initiated with the major plant manufacturers.

- A futures research programme to examine the feasibility of product-service systems in construction is needed.

\section{$\underline{\text { References }}$}

Arup 2006. Drivers of Change. Foresight and Innovation Team, Arup, London.

Bosher, L.S., Dainty, A.R.J., Carrillo, P.M., Glass, J., Price, A.D.F. 2007. Integrating disaster risk management into construction: a UK perspective. Building Research \& Information, March-April, 35(2), 163-177.

Defra/DTI/DCLG 2007. Draft Strategy for Sustainable Construction: A Consultation Paper. Defra/DTI/DCLG, London.

DCLG 2006. Code for Sustainable Homes. Department for Communities and Local Government, London.

ECTP (European Construction Technology Platform) 2005. Challenging and changing Europe's built environment: a vision for a sustainable and competitive construction sector by 2030. ECTP, European Commission, Brussels.

Egan, J. 1998. Rethinking Construction - Report of the Construction Task Force. DETR, London.

Egan, J. 2002. Accelerating Change, A Report for the Strategic Forum for Construction. Construction Industry Council, London.

Egan, J. 2004. Skills for Sustainable Communities. Office of The Deputy Prime Minister, London.

Elzen, B., Geels, F., Green, K. 2004. System Innovation and the Transition to Sustainability: Theory, Evidence and Policy. Edward Elgar, Cheltenham. Fairclough, J. Sir 2002. Rethinking Construction Innovation and Research. Department of Trade and Industry, London. 
Gann, D. 2000. Building Innovation: Complex Constructs in a Changing World. Thomas Telford, London.

Hampson, K., Brandon, P. 2004. Construction 2020: A Vision for Australia's Property and Construction Industry. Cooperative Research Centre for Construction Innovation, Brisbane.

Harty, C., Goodier, C.I., Soetanto, R., Austin, S., Dainty, A.R.J., Price, A.D.F. 2007. The futures of construction: a critical review of construction future studies.

Construction Management and Economics, 25(5), 477-493.

Pearce, D. 2003. The Social and Economic Value of Construction: the Construction Industry's Contribution to Sustainable Development. New Construction Research and Innovation Strategy Panel, London.

Vandemerwe, S., Rada, J. 1988. Servitization of business: adding value by adding services. European Management Journal 6(4), 314-324. 